\title{
Desain Self-Propelled Split Hopper Barge (SPSHB) Pengangkut Pasir untuk Landasan Pacu Program Bandara Terapung Kabupaten Buleleng, Bali
}

\author{
(ITS) \\ e-mail: tita@na.its.ac.id
}

Aditya Permana Putra dan Hesty Anita Kurniawati

Departemen Teknik Perkapalan, Fakultas Teknologi Kelautan, Institut Teknologi Sepuluh Nopember

\begin{abstract}
Abstrak - Bali merupakan destinasi wisatawan domestik maupun mancanegara. Bandara I Gusti Ngurah Rai merupakan pintu gerbang udara dan satu-satunya di Bali. Kepadatan kapasitas Bandara I gusti Ngurah Rai meningkat setiap tahunnya yaitu 74.70 \% pada tahun 2015 dan $87.05 \%$ pada tahun 2016 . Pemerintah Bali mempunyai 11 rencana strategis untuk mengatasi masalah tersebut, satu di antaranya adalah pembangunan Bandara Terapung di Kabupaten Buleleng, Bali Utara. Lokasi tersebut dipilih demi terciptanya pemerataan pembangunan antara Bali selatan dan Bali Utara. Pembangunan itu ditafsir membutuhkan material pasir sebanyak 19-20 juta $\mathbf{m}^{3}$ yang diperoleh dari Pulau Lombok. Untuk memindahkan material tersebut dibutuhkan kapal yang didesain khusus. Jenis kapal yang dipilih adalah jenis Self-Propelled Split Hopper Barge (SPSHB) karena jenis kapal ini memiliki waktu bongkar muatan yang cepat. Metode penelitian yang digunakan untuk mendapatkan ukuran utama SPSHB yang optimum adalah metode optimization dengan bantuan fitur solver dengan menjadikan biaya pembangunan paling minimum sebagai fungsi objektif serta adanya batasan-batasan dari regulasi dan persyaratan teknis yang berlaku. Dari proses optimisasi, di dapatkan hasil ukuran optimum SPSHB adalah $\mathrm{L}=\mathbf{5 8 . 8 1} \mathrm{m}$, $B=13.29 \mathrm{~m}, \mathrm{H}=4.65 \mathrm{~m}, \mathrm{~T}=3.51 \mathrm{~m}$ dengan estimasi biaya pembangunann sebesar 1.979.616,87 USD atau setara dengan Rp.26.560.500.00.
\end{abstract}

Kata Kunci-Bandara terapung, bali, kabupaten buleleng, pasir, self-propeller split hopper barge (SPSHB).

\section{PENDAHULUAN}

B ALI merupakan destinasi wisatawan domestik dan mancanegara. Bali memiliki dua pelabuhan dan satu bandara sebagai akses pintu masuk. Akses menuju Bali melalui jalur udara menjadi pilihan wisatawan domestik dan mancanegara dibandingkan jalur laut. Hal tersebut karena kenyamanan dan waktu tempuh yang cepat bila menggunakan jalur udara. Bandara I Gusti Ngurah Rai adalah pintu gerbang udara dari kegiatan ekonomi utama pariwisata di Indonesia dan satu-satunya pintu gerbang udara untuk Bali. Bandara Ngurah Rai memiliki kapasitas penumpang 17 juta per tahun sedangkan wisatawan tahun 2015 berjumlah 12.7 juta per tahun dan tahun 2016 berjumlah 14.8 juta per tahun [1]. Sehingga dari data tersebut diketahui kepadatan penumpang di
Bandara I gusti Ngurah Rai pada tahun 2015 sebesar 74,70\% dan $87,05 \%$ pada tahun 2016. Kepadatan penumpang di Bandara I Gusti Ngurah Rai dapat berakibat pada aktivitas penerbangan di Bandara tersebut. Masalah yang dapat muncul adalah terjadi penundaan pendaratan pesawat karena pesawat harus berputar-putar di angkasa untuk bergantian melakukan pendaratan. Untuk mengatasi trend peningkatan laju pertumbuhan penumpang di Bandara I Gusti Ngurah Rai, perlu dilakukan perluasan wilayah Bandara I Gusti Ngurah Rai atau dilakukan pembanguanan Bandara baru di Bali.

Bali merupakan salah satu wilayah di Indonesia yang memiliki kesenjangan sosial ekonomi akibat kurang pemerataan pembangunan antara Bali Utara, Bali Barat, Bali Timur dan Bali Selatan. Sehingga Pemerintah Bali mencangkan 11 rencana strategis jangka menengah Bali dalam Rencana Kerja Strategis Badan Pengawasan Keuangan dan Pembangunan Perwakilan Provinsi Bali tahun 2015 - 2019, di mana salah satunya adalah pembangunan Bandar Terapung di Bali Utara. Rekomendasi dari Pemerintah Provinsi Bali wilayah yang akan dijadikan lokasi pembangunan Bandara Terapung adalah Kecamatan Kubutambahan, Kabupaten Buleleng, Provinsi Bali. Total lahan yang direncanakan seluas 1.400 hektare (ha) di mana 264 ha di antaranya merupakan lahan reklamasi, sedangkan sedangkan lahan sisanya murni di atas laut yang tidak memungkinkan reklamasi karena kedalamannya mencapai $500 \mathrm{~m}$ [2]. Pembangunan tersebut ditafsir membutuhkan material pasir sebanyak $19-20 \mathrm{~m}^{3}$ [3]. Pasir yang digunakan untuk memenuhi kebutuhan pasir tersebut adalah pasir Lombok di karenakan Lombok memiliki potensi pasir sebanyak 60 juta $\mathrm{m}^{3}$ [4].

\section{TINJAUAN PUSTAKA}

\section{A. Bandara Terapung}

Bandara adalah tempat persawat terbang diperkenankan mendarat dan berangkat langsung [5]. Apung adalah sesuatu yang tidak tengelam dipermukaan air [6]. Bandara terapung adalah suatu tempat mendarat dan berangkat kapal yang berada dilautan. Bandara Terapung merupakan salah satu masterplan dari pemerintah Indonesia untuk menunjang 
pertumbuhan pariwisata dan menarik wisatawan asing.

\section{B. Pemilihan Jenis Kapal}

Pemilihan jenis kapal dan kapasitas kapal keruk ditentukan oleh:

a. Maksud dan tujuan dilakukan pengerukan (pemeliharaan kedalaman alur/kolam pelabuhan dann pembuatan alur/kolam pelabuhan);

b. Kedalaman awal alur atau kolam;

c. Lokasi pekerjaan;

d. Jenis material keruk (pasir, lumpur, tanah liat/clay dan karang);

e. Volume Keruk;

f. Jarak ke area pembuangan [7]

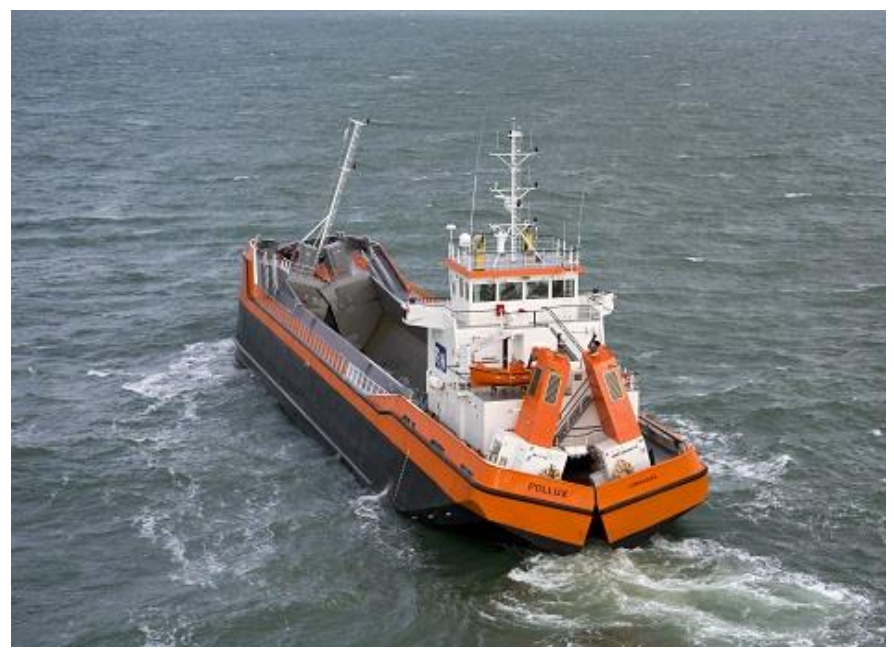

Gambar 1. Self Propelled Hopper Barge [8]

Dari karekteristik diatas maka dipilih kapal Self-Propelled Split Hopper Barge (SPSHB). SPSHB merupakan jenis kapal tongkang yang memiliki sistem penggerak sendiri yang dirancang untuk mengangkut muatan pasir, batu atau lumpur yang di tujukan untuk kepentingan reklamasi. SPSHB merupakan perpaduan antara Split Barge dan Self-Proplled Hopper Barge. Dimana kapal tersebut dapat menuangkan muatan seperti kapal Split Barge dan dapat membawa sendiri muatan dari tempat asal seperti Self-Proplled Hopper Barge. . Pada Gambar. 1. terlihat bahwa Self-Propelled Split Hopper Barge Self-Unloading. SPSHB saat ini mulai marak digunakan sebagai moda transportasi pengangkut muatan untuk reklamasi di Indonesia. Hal itu terjadi karena Indonesia sedang gencargencarnya melakukan pembangunan di sejumlah pesisir

\section{Tinjauan Wilayah}

Bandara Terapung, Bali memiliki luasan sebesar 100 Ha. Pasir yang dibutuhkan utnuk membuat bandara terapung sebesar 19 - 20 juta $\mathrm{m}^{3}$ [3]. Pasir yang digunakan untuk memenuhi pembangunan Bandara Terapung adalah pasir Pulau Lombok. Pada Gambar. 2. terlihat bahwa Jalur Pelayaran Kapal SPHSB jalur pelayaran kapal SPSHB berawal dari Pelabuhan Lembar, Lombok menuju Kab. Buleleng, Bali. Pelayaran tersebut menempuh jarak $125 \mathrm{~km}$. SPSHB melewati perairan selat Bali dimana arus perairan selat Bali yaitu tenang, sehingga kecil kemungkinan kapal mengalami ganguan stabilitas saat melakukan pelayaran.

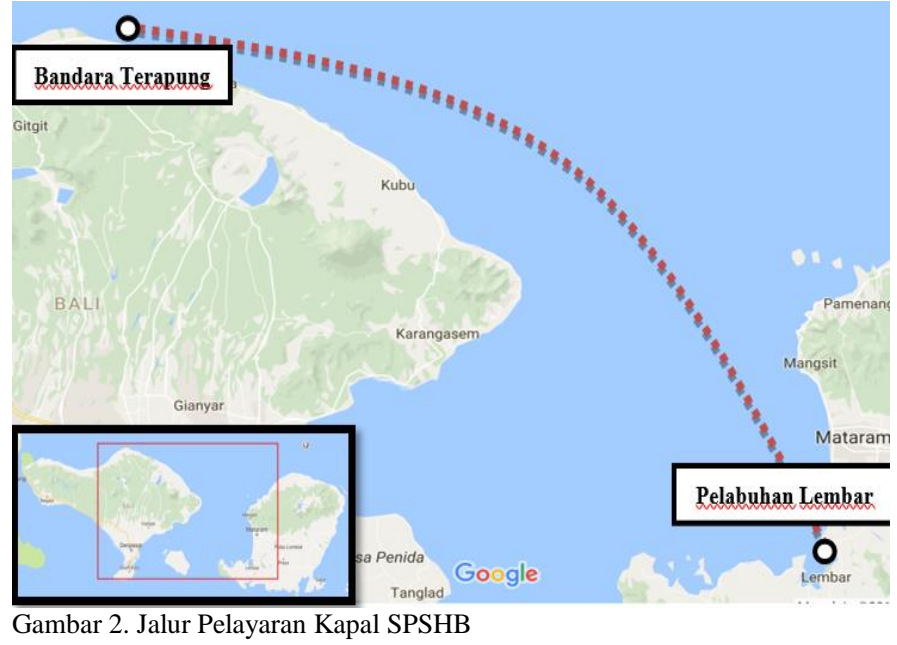

\section{METEDOLOGI PENELITIAN}

\section{A. Diagram Alir}

Tahapan dari metodologi penelitian yang digunakan dalam pengerjaan Studi digambarkan pada diagram alir pada Gambar 3 :

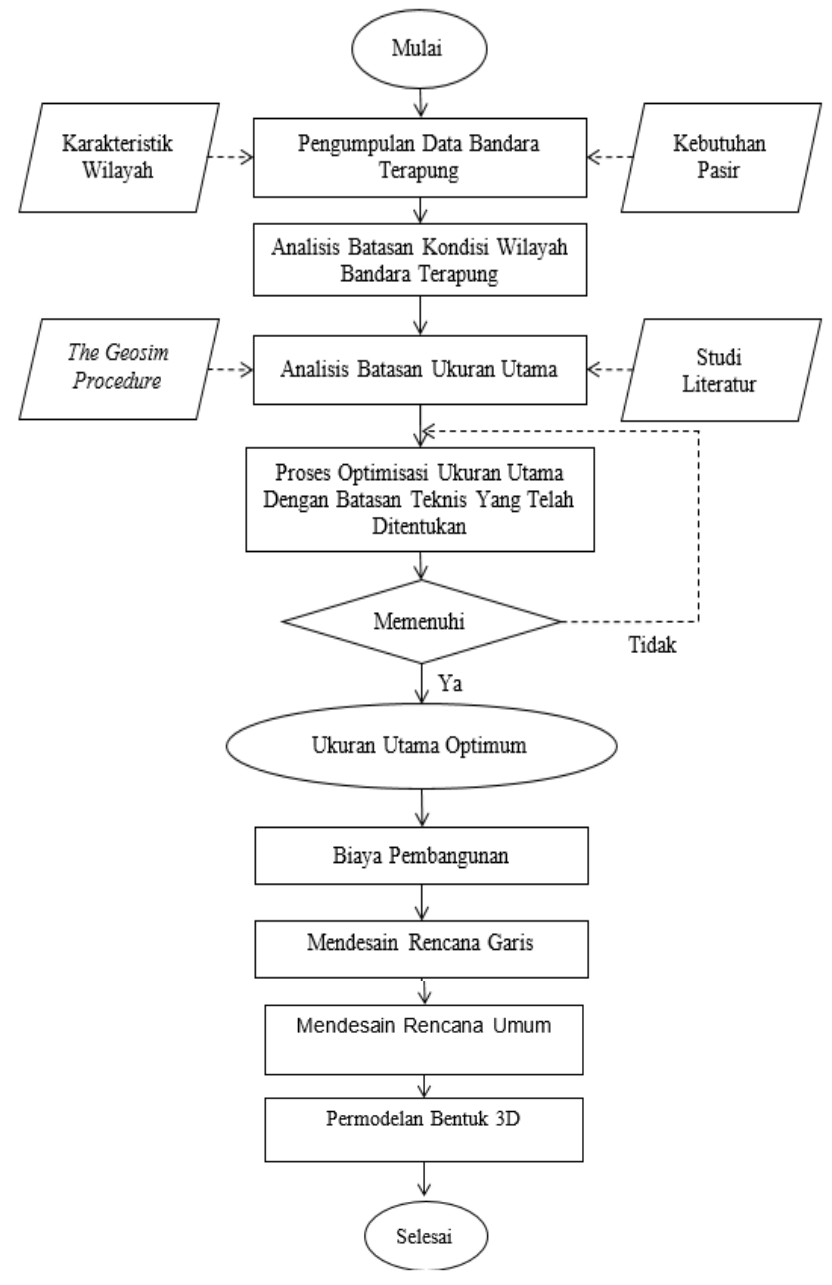

Gambar 3. Diagram Alir 


\section{B. Optimisasi Ukuran Utama}

Metode optimisasi adalah metode yang digunakan untuk mencari nilai optimum baik itu nilai maksimum ataupun minimum dari suatu fungsi matematis. Pada metode ini, fungsi tidak dapat berdiri sendiri tanpa adanya batasan-batasan, oleh karena itu sebelum dilakukannya perhitungan dengan metode tersebut, harus terlebih dahulu dilakukan penentuan objective function, variable, constrain, parameter, dan constanta. Pada Gambar 4. terlihat bahwa model optimisasi SPSHB.

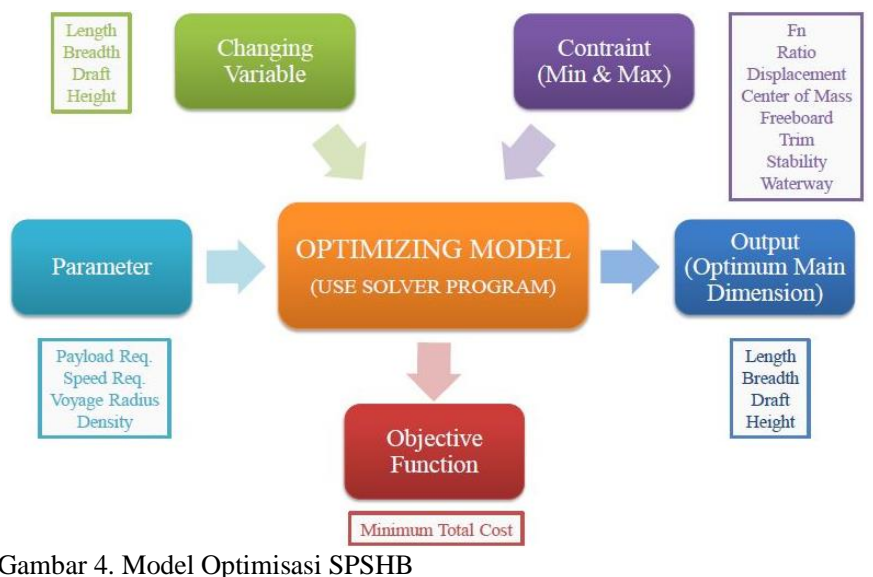

\section{ANALISIS TEKNIS SPLIT HOPPER BARGE}

\section{A. Desain Statement}

Dari latar belakang masalah yang ada di atas, maka dapat disimpulkan data owner requirement dari Pembangunan Bandara Terapung Kabupaten Buleleng, Bali adalah sebagai berikut:

1. Jenis kapal yang digunakan untuk program ini adalah SelfPropelled Split Hopper Barge (SPSHB), mengingat kapal SPSHB memiliki kelebihan kecepatan proses bongkar muat.

2. Jenis muatan yang akan dimuat adalah pasir kering sesuai dengan program yang dicanangkan untuk memngangkut pasir dari kawasan Lombok yaitu 20 juta m3.

3. Kapal milik Pemerintah

4. Waktu pembangunan Bandara Terapung selama 5 tahun [9]

5. Kapal didesain dengan kecepatan 8 knot $(4,116 \mathrm{~m} /$ detik $)$, dengan estimasi waktu pelayaran normal yang dibutuhkan adalah 9 jam untuk pelayaran satu arah.

6. Radius pelayaran dari Kab. Bulelng menuju Pelabuhan Lembar Lombok sepanjang $125 \mathrm{~km}$.

\section{B. Penentuan Model Optimisasi}

Metode penentuan ukuran utama yang digunakan dalam penelitian ini adalah dengan menggunakan metode optimisasi yang dibantu dengan penggunaan fitur Solver pada perangkat lunak Microsoft Excel. Dimana ukuran utama kapal menjadi Changing Variabel, batasan teknis seperti froude number, rasio ukuran utama, koreksi displesemen, koreksi titik berat dan freeboard menjadi Constraint dan harga pembangunan kapal menjadi Objective Function.

\section{Analisis Teknis Terhadap Hasil Optimisasi SPSHB}

Setelah dilakukan proses optimisasi, maka didapatkan ukuran utama optimal SPSHB yang telah memenuhi batasan teknis dan regulasi yang ada dengan estimasi biaya pembangunan paling efisien (murah). Rekapitulas ukuran utama optimum dapat dilihat pada Tabel 1. sebagai berikut:

Tabel 1.

Rekapitulasi Rasio dan Koefisien SPSHB

\begin{tabular}{ccc}
\hline \hline Komponen & Nilai & Satuan \\
\hline Length $\left(\mathrm{L}_{\mathrm{PP}}\right)$ & 58.81 & $\mathrm{~m}$ \\
Length $\left(\mathrm{L}_{\mathrm{WL}}\right)$ & 61.17 & $\mathrm{~m}$ \\
Breadth $(\mathrm{B})$ & 13.29 & $\mathrm{~m}$ \\
Draft $(\mathrm{T})$ & 3.51 & $\mathrm{~m}$ \\
Height $(\mathrm{H})$ & 4.65 & $\mathrm{~m}$ \\
Vol. Disp. $(\overline{\mathrm{v}})$ & 2344.73 & $\mathrm{~m}^{3}$ \\
Disp. Ton $(\Lambda)$ & 2403.35 & ton \\
\hline \hline
\end{tabular}

Dari hasil ukuran utama yang didapatkan, maka dapat ditentukan besarnya hambatan kapal, kebutuhan daya mesin induk, berat, dan freeboard. Dari masing-masing ukuran utama tersebut, didapatkan rasio ukuran utama dan koefisien kapal. Rekapitulasi rasio dan koefisien dapat dilihat pada Tabel 2. sebagai berikut:

Tabel 2.

Rekapitulasi Rasio dan Koefisien SPSHB

\begin{tabular}{cc}
\hline \hline Rasio/Koefisien & Nilai \\
\hline $\mathrm{L} / \mathrm{B}$ & 4.425 \\
$\mathrm{~B} / \mathrm{T}$ & 3.790 \\
$\mathrm{~L} / \mathrm{T}$ & 16.770 \\
$\mathrm{C}_{\mathrm{B}}$ & 0.822 \\
$\mathrm{C}_{\mathrm{M}}$ & 0.996 \\
$\mathrm{C}_{\mathrm{P}}$ & 0.826 \\
$\mathrm{C}_{\mathrm{WP}}$ & 0.890 \\
\hline \hline
\end{tabular}

Setelah didapatkan rasio ukuran utama dan koefisien maka selanjutnya dilakukan perhitungan besar hambatan kapal berdasarkan perhitungan hambatan kapal tongkang [10] dan kebutuhan daya mesin induk dengan dua rangkaian sistem penggerak (twin screw), Rekapitulasi Resistance dan Powering dapat dilihat pada Tabel 3. sebagai berikut:

Tabel 3.

Rekapitulasi Resistance dan Powering SPSHB

\begin{tabular}{crl}
\hline \hline Komponen & Nilai \\
\hline $\mathrm{R}_{\mathrm{T}}$ & 48.300 & $\mathrm{kN}$ \\
$\mathrm{P}_{\text {Req. }}$ & 292.373 & $\mathrm{x} 2 \mathrm{~kW}$ \\
$\mathrm{P}_{\text {MainEngine }}$ & 298 & $\mathrm{x} 2 \mathrm{~kW}$ \\
$\mathrm{P}_{\text {GenReq. }}$ & 73.093 & $\mathrm{x} 2 \mathrm{~kW}$ \\
$\mathrm{P}_{\text {Generator }}$ & 82.9 & $\mathrm{x} 2 \mathrm{~kW}$ \\
\hline \hline
\end{tabular}

Kebutuhan daya mesin induk pada SPSHB dapat berdampak pada perbedaan besar berat yang dihasilkan, karena adanya komponen berat kapal yang merupakan fungsi dari BHP. Perbedaan sarat dan tinggi kapal juga berdampak pada perbedaan freeboard. Rekapitulasi berat - titik berat dan freeboard dapat dilihat pada Tabel 4. sebagai berikut: 
Tabel 4.

Rekapitulasi Berat - Titik Berat dan Freeboard SPSHB

\begin{tabular}{crl}
\hline \hline Komponen & \multicolumn{1}{c}{ Nilai } & \multicolumn{1}{c}{ Satuan } \\
\hline DWT & 1571.718 & ton \\
LWT & 783.562 & ton \\
LWT+DWT & 2355.200 & ton \\
LCB & 28.15 & $\mathrm{~m}(\mathrm{FP})$ \\
LCG & 28.762 & $\mathrm{~m}(\mathrm{FP})$ \\
Freeboard & 1145 & $\mathrm{~mm}$ \\
\hline \hline
\end{tabular}

Perhitungan stabilitas disyaratkan dalam IS (Intact Stability) Code [11]. Rekapitulasi stabilitas tidak membelah dan membelah dapat dilihat pada Tabel 5. Dan Tabel 6. sebagai berikut:

Tabel 5 .

Rekapitulasi Stabilitas SPSHB

\begin{tabular}{cccccc}
\hline \hline $\begin{array}{c}\text { Load } \\
\text { Case }\end{array}$ & $\begin{array}{c}\mathrm{e} 0-30^{\circ} \\
(3.15 \mathrm{~m} . \mathrm{deg})\end{array}$ & $\begin{array}{c}\mathrm{e} 30-40^{\circ} \\
(5.15 \mathrm{~m} . \mathrm{deg})\end{array}$ & $\begin{array}{c}\mathrm{GZ} 30^{\circ} \\
(0.2 \mathrm{~m})\end{array}$ & $\begin{array}{c}\mathrm{GM}^{\circ} \\
(0.15 \mathrm{~m})\end{array}$ & $\begin{array}{c}\phi^{\circ} \max \\
\left(25^{\circ}\right)\end{array}$ \\
\hline 1 & 82,916 & 37,950 & 3,852 & 21.045 & 28,2 \\
2 & 82,740 & 37,801 & 3,840 & 20.842 & 28,2 \\
3 & 82,411 & 37,559 & 3,819 & 20.584 & 28,2 \\
4 & 72,883 & 33,656 & 3.448 & 17.025 & 28,1 \\
5 & 65,732 & 33,601 & 3.445 & 16.910 & 28,1 \\
6 & 64,684 & 33,500 & 3.436 & 16.756 & 28,1 \\
7 & 71,396 & 33,759 & 3.458 & 16.716 & 28,2 \\
8 & 71,326 & 33,725 & 3.455 & 16.703 & 28,2 \\
9 & 71,185 & 33,647 & 3.448 & 17.031 & 28,2 \\
Status & Pass & Pass & Pass & Pass & Pass \\
\hline \hline
\end{tabular}

Tabel 6.

Rekapitulasi Stabilitas SPSHB (Un-Loading)

\begin{tabular}{|c|c|c|c|c|c|}
\hline $\begin{array}{l}\text { Load } \\
\text { Case }\end{array}$ & $\begin{array}{c}\mathrm{e} 0-30^{\circ} \\
(3.15 \mathrm{~m} \cdot \mathrm{deg})\end{array}$ & $\begin{array}{c}\text { e } 30-40^{\circ} \\
(5.15 \mathrm{~m} . \mathrm{deg})\end{array}$ & $\begin{array}{l}\mathrm{GZ} \mathrm{30} 0^{\circ} \\
(0.2 \mathrm{~m}) \\
\end{array}$ & $\begin{array}{c}\mathrm{GM} \mathrm{0}^{\circ} \\
(0.15 \mathrm{~m}) \\
\end{array}$ & $\begin{array}{c}\phi^{\circ} \max \\
\left(25^{\circ}\right) \\
\end{array}$ \\
\hline 1 & 83,468 & 49,153 & 5.075 & 11.574 & 42.9 \\
\hline 2 & 83,208 & 48,818 & 5.037 & 11,671 & 42,9 \\
\hline 3 & 82,766 & 48,333 & 4,982 & 11.749 & 41,9 \\
\hline 4 & 76,999 & 43,194 & 4.406 & 12,246 & 41 \\
\hline 5 & 76,865 & 43,030 & 4.388 & 12,317 & 41 \\
\hline 6 & 77,621 & 42,777 & 4.360 & 12,391 & 41 \\
\hline 7 & 76,378 & 40,874 & 4.118 & 13,354 & 39 \\
\hline 8 & 76,225 & 40,759 & 4.106 & 13,414 & 39 \\
\hline 9 & 76,038 & 40,578 & 4.087 & 13,484 & 39 \\
\hline Status & Pass & Pass & Pass & Pass & Pass \\
\hline
\end{tabular}

D. Pembuatan Rencana Garis, Rencana Umum SPSHB dan Permodelan 3D

1. Rencana Garis

Setelah didapatkan ukuran utama yang optimum, maka dilanjutkan dengan pembuatan rencana garis SPSHB dengan memperhatikan dan menyesuaikan kriteria teknis, seperti ukuran utama, koefisien, berat dan titik berat kapal. Desain Rencana Garis SPSHB dapat dilihat pada Gambar. 5. sebagai berikut:

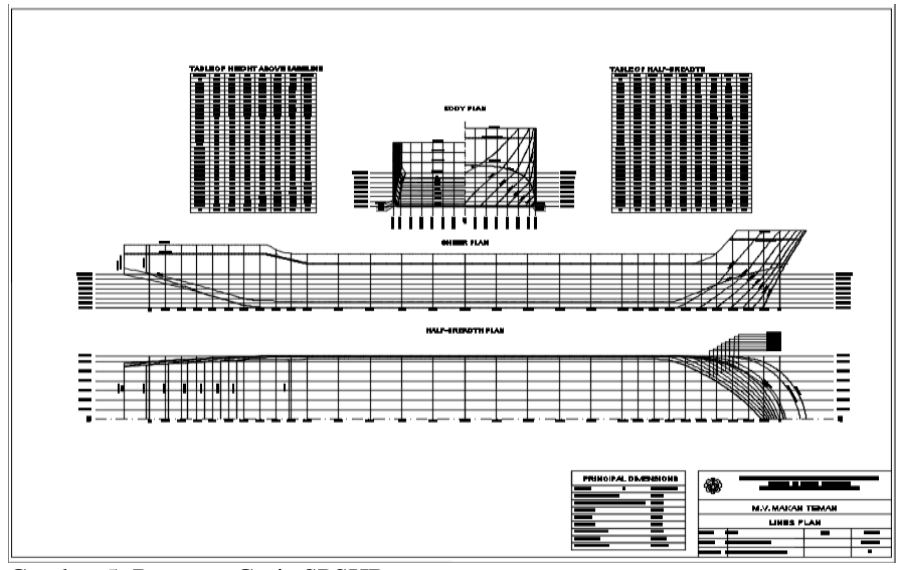

Gambar 5. Rencana Garis SPSHB

\section{Rencana Umum}

Proses pembuatan desian rencana umum dilakukan dengan memperhatikan perencanaan dan pembagian ruang akomodasi untuk semua kebutuhan dan perlengkapan kapal sesuai lokasi dan akses serta letak tangki-tangki yang dibutuhkan sesuai dengan peraturan dan regulasi yang ada. Desain Rencana Umum SPSHB dapat dilihat pada Gambar. 6. sebagai berikut:

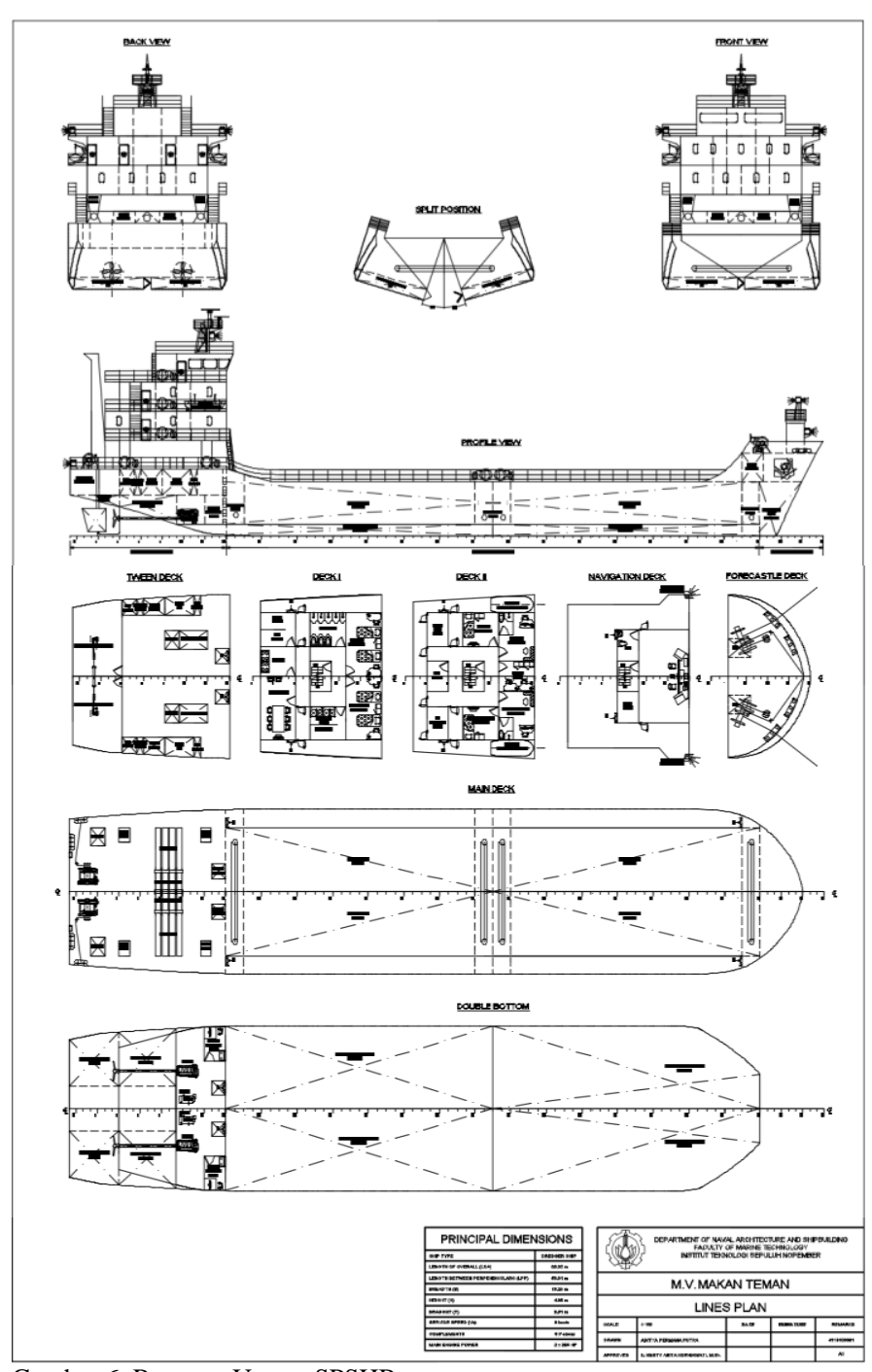




\section{Permodelan 3D}

Pembuatan model kapal ini harus sesuai dengan ukuran utama kapal dengan bentuk lambung yang menyerupai kapal tersebut serta perlengkapan kapal disesuaikan dengan gambar rencana umum yang ada. Untuk permodelan 3 dimensi sebagai berikut:

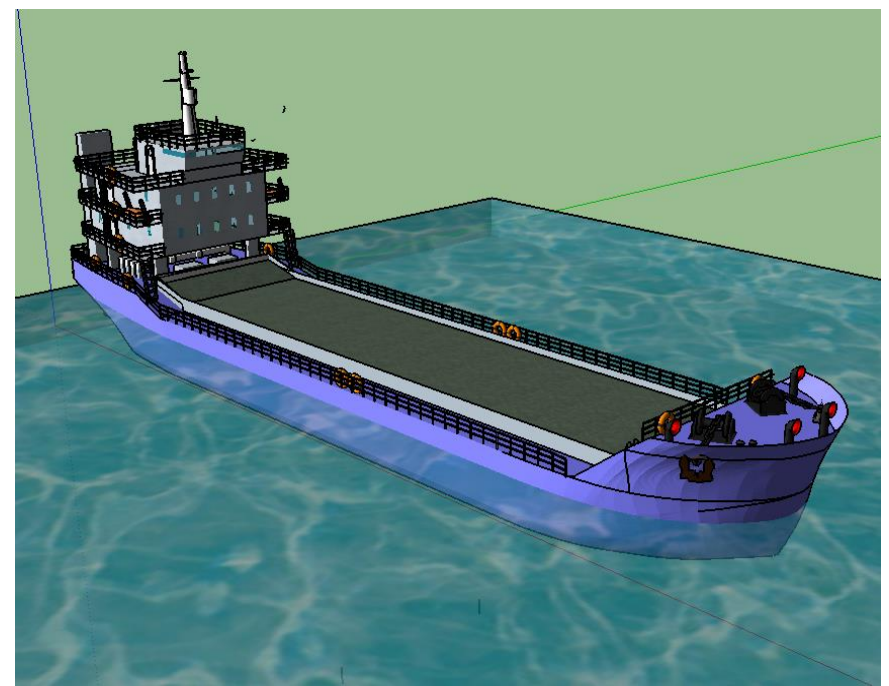

(a)

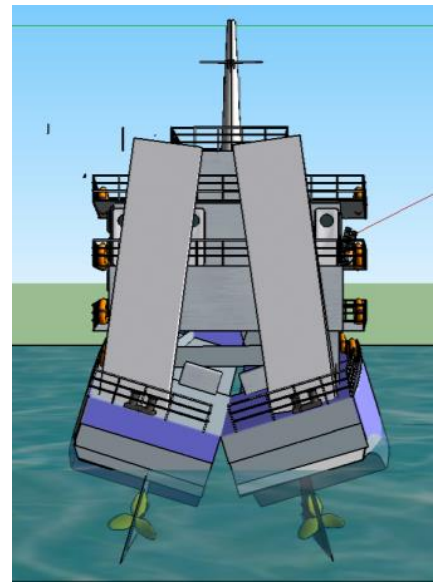

(b)

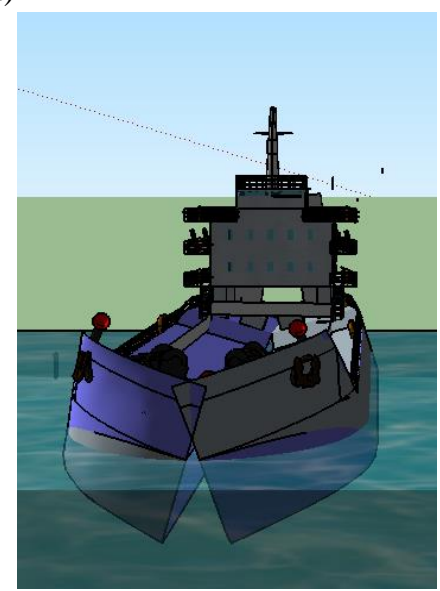

(c)
Gambar 7. (a) Permodelan 3D SPSHB Pembelahan Lambung, (b) Tampak Belakang, (c) Tampak Depan.

\section{ANALISIS EKONOMIS SPLIT HOPPER BARGE}

Setelah seluruh kriteria teknis memenuhi persyaratan, maka besar biaya pembangunan dapat ditentukan dengan persentase biaya pembangunan berdasarkan modul Estimasi Harga Pembangunan Kapal Baru [12].

Tahapan pertama dalam melakukan estimasi biaya pembangunan adalah menentukan komponen biaya yang dijadikan acuan, Acuan tersebut adalah biaya dari komponen baja yang dibutuhkan. Besar biaya komponen baja didapatkan dari berat baja kapal yang dikalikan dengan harga baja per satuan ton. Untuk perhitungan biaya ekonomis lebih detail sebagai berikut:

$$
\begin{aligned}
\$ \text { Steel Plate } & =\mathrm{W}_{\mathrm{S}} \times \mathrm{UP}_{\mathrm{S}} \\
\mathrm{W}_{\mathrm{S}} & =558.110 \text { ton } \\
\mathrm{UP}_{\mathrm{S}} & =\text { Unit Price } \text { Baja } \\
& =\$ 747.0 / \text { ton }[13]
\end{aligned}
$$

$\$$ Steel Plate $=\$ 416.908,43$
$\%$ Total Cost $=21 \%$

Setelah diketahui besar harga komponen baja yang dibutuhkan, maka dihitung biaya pembangunan dari komponen lainnya berdasarkan harga baja yang dijadikan acuan dan persentase dari masing-masing komponen. Contoh perhitungan biaya dari persentase yang ada didapatkan sebagai berikut:

$\$$ Komponen $=(\%$ Komponen $/ \%$ Acuan $) \times \$$ Acuan Sebagai contoh mencari biaya dari design cost (\$ Desain)

$$
\begin{aligned}
\% \text { Desain } & =3.00 \%(\text { Total Cost }) \\
\% \text { Acuan } & =\% \text { Steel and profile } \\
& =21.00 \%(\text { Total Cost }) \\
\$ \text { Acuan } & =\$ \text { Steel and profile } \\
& =\$ 416.908,43 \\
\% \text { Desain } & =(3.00 / 21.00) \times 416.908,43 \\
& =\$ 59.558,35
\end{aligned}
$$

\begin{tabular}{|c|c|c|c|}
\hline Cost & Detail & $\%$ & $\$$ \\
\hline \multirow{33}{*}{$\begin{array}{l}5 \\
0 \\
0 \\
0 \\
0 \\
0 \\
0 \\
0\end{array}$} & 1. Hull Part & & \\
\hline & 1.a. Steel plate and profile & 21.00 & $\$ 416.908,43$ \\
\hline & $\begin{array}{l}\text { 1.b. Hull outfit, deck machiney and } \\
\text { accommodation }\end{array}$ & 7.00 & $\$ 138.969,48$ \\
\hline & 1.c. Piping, valves and fittings & 2.50 & $\$ 49.631,96$ \\
\hline & 1.d. Paint and cathodic protection/ICCP & 2.00 & $\$ 39.705,57$ \\
\hline & 1.e. Coating (BWT only) & 1.50 & $\$ 29.779,17$ \\
\hline & $\begin{array}{l}\text { 1.f. Fire fighting, life saving and safety } \\
\text { equipment }\end{array}$ & 1.00 & $\$ 19.852,78$ \\
\hline & 1.g. Hull spare part, tool, and inventory & 0.30 & $\$ 5.955,83$ \\
\hline & Subtotal (1) & 35.30 & $\$ 69.847,40$ \\
\hline & 2. Machinery Part & & \\
\hline & 2.a. Propulsion system and accessories & 12.00 & $\$ 238.233,39$ \\
\hline & $\begin{array}{l}\text { 2.b. Auxiliary diesel engine and } \\
\text { accessories }\end{array}$ & 3.50 & $\$ 69.484,74$ \\
\hline & 2.c. Boiler and Heater (Tidak Ada) & 1.00 & $\$ 0$ \\
\hline & 2.d. Other machinery in in $E / R$ & 3.50 & $\$ 69.484,74$ \\
\hline & 2.e. Pipe, valves, and fitting & 2.50 & $\$ 49.631,96$ \\
\hline & 2.f. Machinery spare part and tool & 0.50 & $\$ 9.926,39$ \\
\hline & Subtotal (2) & 23.00 & $\$ 436.761,22$ \\
\hline & 3. Electric Part & & \\
\hline & $\begin{array}{l}\text { 3.a. Electric power source and } \\
\text { accessories }\end{array}$ & 3.00 & $\$ 59.558,35$ \\
\hline & 3.b. Lighting equipment & 1.50 & $\$ 29.778,17$ \\
\hline & 3.c. Radio and navigation equipment & 2.50 & $\$ 49.631,96$ \\
\hline & 3.d. Cable and equipment & 1.00 & $\$ 19.852,78$ \\
\hline & 3.e. Electric spare part and tool & 0.20 & $\$ 3.970,56$ \\
\hline & Subtotal (3) & 8.20 & $\$ 162.792,82$ \\
\hline & 4. Construction cost & & \\
\hline & $\begin{array}{l}\text { Consumable material, rental equipment } \\
\text { and labor }\end{array}$ & 20.00 & $\$ 397.055,65$ \\
\hline & Hydraulic & - & $\$ 40.000,00$ \\
\hline & Subtotal (4) & 20.00 & $\$ 437.055,65$ \\
\hline & 5. Launching and testing & & \\
\hline & Subtotal (5) & 1.00 & $\$ 19.852,78$ \\
\hline & 6. Inspection, survey and certification & & \\
\hline & Subtotal (6) & 1.00 & $\$ 19.852,78$ \\
\hline & TOTAL I $(\operatorname{sub} 1+2+3+4+5+6)$ & 88.50 & $\$ 1,751.309,87$ \\
\hline & 7. Design cost & 3.00 & $\$ 59.558,35$ \\
\hline & 8. Insurance cost & 1.00 & $\$ 19.852,78$ \\
\hline
\end{tabular}

Dari contoh perhitungan di atas, maka didapatkan besar biaya pembangunan dengan rincian seperti pada tabel berikut:

Tabel 7.

Estimasi Biaya Pembanguna SPSHB 
9. Freight cost, import duties, IDC, $Q / A$, guarantee engineer, handling fee, $\quad 2.50 \quad \$ 49.631,96$ guarantee \& warranty cost.

$\begin{array}{lll}\text { TOTAL II }(\text { sub } 7+8+9) & 6.50 & \$ 129.043,09\end{array}$

$\begin{array}{llr}\text { TOTAL III (MARGIN) } & 5.00 & \$ 99.263,91\end{array}$

$\begin{array}{lr}\text { GRAND TOTAL }(I+I I+I I I) & 100.00 \quad \$ 1,979.616,87\end{array}$

\section{KESIMPULAN}

Berdasarkan uraian Jurnal ini dapat disimpulkan sebagai berikut:

1. Dari hasil analisis teknis berupa proses optimisasi dengan fungsi tujuan biaya pembangunan paling minimum, maka didapatkan ukuran utama SPSHB sebagai berikut:

- Length of waterline (LWL) : 61.17 meter

- Length of perpendicular (Lpp) : 58.81 meter

- Breadth (B)

: 13.29 meter

- Height $(\mathrm{H})$

: 4.65 meter

- Draught (T)

: 3.51 meter

2. Dari hasil analisis ekonomis yang meliputi biaya pembanguna dari desai SPSHB didapatkan total estimasi biaya pembanguan sebesar 1.979.616,87 USD atau setara dengan Rp. 26.560.500.000
3. Proses bongkar muat dilakukan di Pelabuhan Lembar, Lombok dan Kabupaten Buleleng, Bali di mana proses muat dibantu oleh hydraulic excavator. Dibutuhkan waktu sekitar 1 jam 20 menit untuk satu kali proses muat dan proses bongkar muatan dilakukan dengan cara kapal melakukan pembelahan lambung.

\section{DAFTAR PUSTAKA}

[1]

A. P. II, "Daya Tampung Bandara I Gusti Ngurah Rai Terbesar di Indonesia," 2013. [Online]. Available: https://www.ap1.co.id/id/information/newsdetail/daya-tampung-bandara-i-gusti-ngurah-rai-menjadi-yang-terbesar-diindonesia-saat-ini.

[2] A. Domanski, "Airport Kinesis Siap Bangun Bandara Baru di Buleleng Bali," Tempo, 2016.

[3] D. Agustina, "Bandara Buleleng Bakal Terapung di Atas Laut," Tribunnews, 2016.

[4] S. Khafid, "30 Juta Kubik Pasir Laut Lombok untuk Reklamasi Teluk Benoa," Tempo, 2016.

[5] K. B. B. Indonesia, "Pengertian Bandara," Kamus Besar Bahasa Indonesia, 2016. [Online]. Available: http://kbbi.web.id/bandara.

[6] K. B. B. Indonesia, "Pengertian Apung," Kamus Besar Bahasa Indonesia, 2016. [Online]. Available: http://kbbi.web.id/apung.

[7] M. R. . Jaelani, "Desain Dredger Berbasis Jalur Sungai Pada Program Tol Sungai Cikarang Bekasi Laut (CBL) - Tanjung Priok," J. POMITS, vol. 5, no. 2, 2016.

[8] Google, "Split Hopper Barge," Google, 2016. [Online]. Available: http://www.google.co.id/search?q=split+hopper+barge.

[9] M. I. N. A, "Bandara Dengan Konsep Megafloat sebagai Solusi Pemerataan Pembangunan Bali Utara," Universitas Pendidikan Ganesha, 2013.

[10] K. R. (KR), Rules for Towing Survey of Barges and Tugboats perubahan dari (Rules 1999). 2010.

[11] I. M. O. (IMO), International Stability, 1974, perubahan dari (SOLAS 1974). London: IMO, 2009.

[12] PERTAMINA, Estimasi Harga Pembangunan Kapal Baru. 2007. 